\title{
Red Abalone, Sea Otters, and Kelp Forest Ecosystems on Historic Period San Miguel Island, California
}

\author{
Todd J. Braje, San Diego State University \\ Jon M. Erlandson, Museum of Natural and Cultural History, University of Oregon \\ Torben C. Rick, National Museum of Natural History, Smithsonian Institution
}

\section{Introduction}

With prominent marine scientists calling for deeper historical perspectives to overcome the "shifting baselines" syndrome and help restore fisheries and ecosystems degraded by human overexploitation (e.g., Dayton et al. 1998; Jackson et al. 2001; Lotze et al. 2006; Pauly et al. 1998; Worm et al. 2006), archaeological data play an increasingly significant role in documenting the structure of past fisheries and foodwebs (see Rick and Erlandson 2008). Recent archaeological and historical ecological research on California's Northern Channel Islands (Figure 1) has focused on building trans-Holocene sequences of human-environmental dynamics to better understand the long histories of local marine ecosystems and the effects of human exploitation on them (Braje 2010; Braje et al. 2009; Erlandson et al. 2008, 2011a; Rick et al. 2008). One line of research has investigated possible links between prehistoric human hunting of sea otters, shellfish harvesting, and human induced trophic cascades beginning about 7500 years ago (Braje et al. 2009; Erlandson et al. 2005).

Sea otters play an important role in structuring North Pacific kelp forest ecosystems (Dayton 1985; Dayton and Tegner 1984; Simenstad et al. 1978). When feeding in kelp forests, sea otters focus on abalones (Haliotis spp.), sea urchins (Strongylocentrotus spp.), and crabs, shifting to California mussels (Mytilus californianus), other shellifish, and fish when their preferred prey is unavailable (Estes et al. 1981). In Alaska and British Columbia, the historical removal or reduction of sea otters has resulted in local kelp deforestation by sea urchin blooms, trophic cascades, and reduced marine biodiversity and productivity in nearshore ecosystems (Estes and Duggins 1995; Simenstad et al. 1978). In Southern California and the Channel Islands, kelp forest foodwebs are more complex, stable, and resilient (Graham et al. 2008; Steneck et al. 2002). Despite the historic decimation of sea otter populations in the mid-1800s, there has been no 
wholesale collapse of kelp forests since California sheephead (Semicossyphus pulcher), sunflower stars (Picnopodia helianthoides), spiny lobsters (Panulirus interruptus), and humans also prey on urchins and help control their populations when sea otters are reduced.

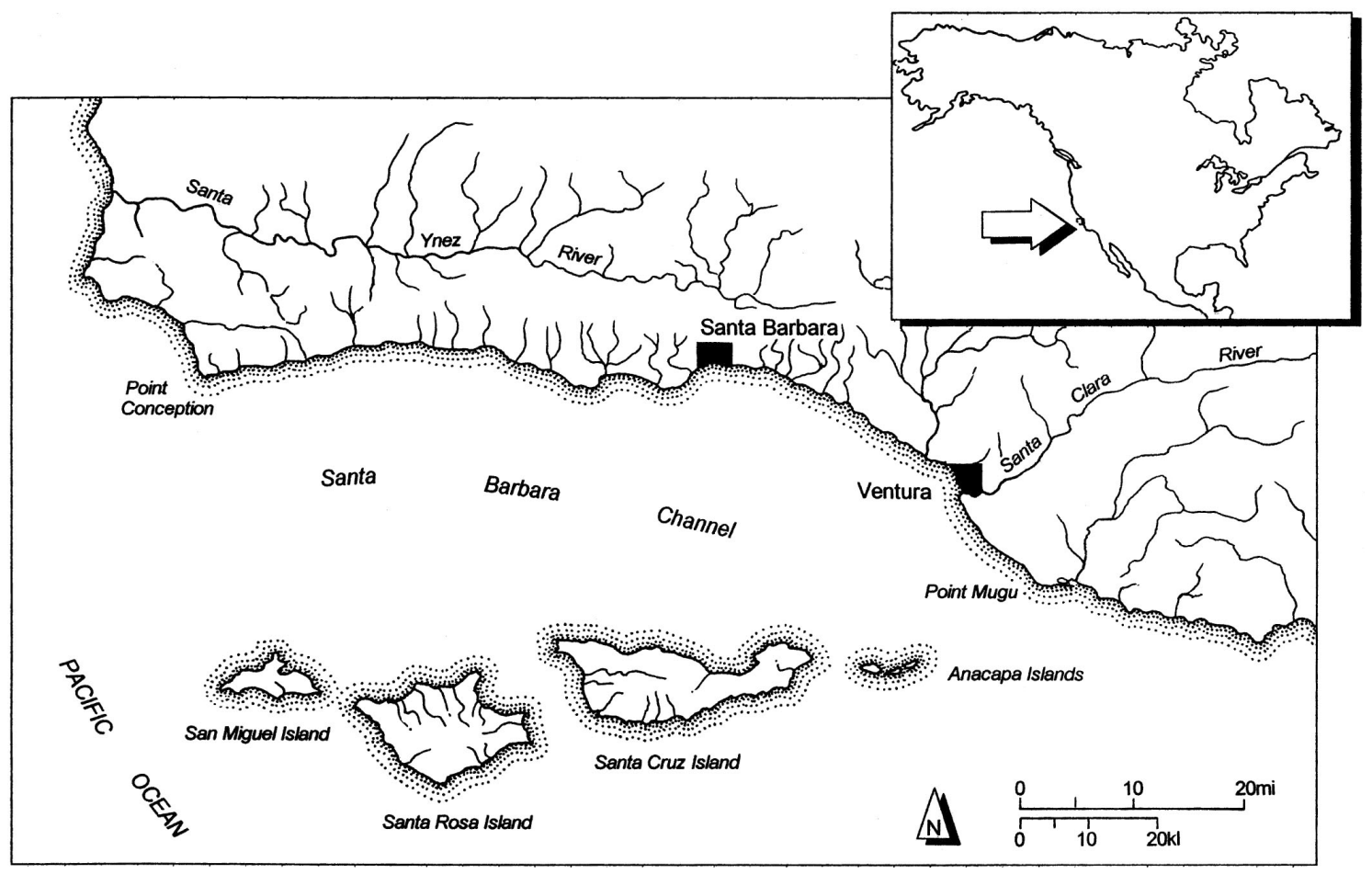

Figure 1. The location of the Northern Channel Islands and the Santa Barbara Channel off the coast of California.

Source: Adapted from Kennett (2005).

Dayton (1985:234) and Dayton and Tegner (1984:471) argued that Native American hunters may have controlled sea otter populations along the California Coast, releasing shellfish populations from predation and increasing their size and abundance. Using archaeological data to test this hypothesis, Erlandson et al. $(2005,2008)$ suggested that the Island Chumash and their ancestors hunted otters on San Miguel from at least 9000 years ago until the Historic Period, increasing the productivity of nearshore shellfish communities. They argued that the exceptional size and abundance of red abalone (Haliotis rufescens) shells and the presence of sea urchin lenses (dense concentrations of sea urchin tests) from numerous Northern Channel Island shell middens dated between $\sim 8000$ and 3000 years ago (also see Braje et al. 2009; Sharp 2000) provided evidence for prehistoric sea otter exploitation and anthropogenic changes in local shellfisheries. Whether such changes were an inadvertent by-product of otter hunting or part of an intentional environmental management strategy is difficult to determine using archaeological data.

Sea otter remains have been found in numerous San Miguel Island sites dating between about 9000 and 200 years ago, but the sample sizes for most sites and time periods are relatively low (Erlandson et al. 2005). In particular, there is relatively little faunal evidence for otter hunting prior to 7500 years ago, when large red abalone middens first appear widely in the archaeological record. Technological evidence, in the form of numerous finely-made stemmed and barbed projectile points, has emerged recently to suggest that marine hunting was an important activity on San Miguel and the other Northern Channel Islands between $-12,000$ and 8000 years ago (Braje 2010; Erlandson et al. 2009, 2011b; Glassow et al. 2008). There is also evidence of increasing demographic expansion through the Early, Middle, and Late Holocene. Likely, the islands were being used more intensively, by larger groups of hunter-foragers through the Early to 
Middle Holocene, with clear evidence for the first permanent island villages at the beginning of the Late Holocene ( -3500 years ago). This would have resulted in increasing predation pressure on both shellfish and sea otters. A deeper understanding of the long history of interaction between humans, otters, and abalones might prove useful in designing conservation programs aimed at restoring healthy otter populations and re-establishing a productive abalone fishery in Southern California (Braje et al. 2009).

In this chapter, we provide a new dataset to help test the intensity of ancient sea otter hunting on the Northern Channel Islands. We report on the largest assemblage of historic red abalone shell measurements from California's Northern Channel Islands, data gathered from a $19^{\text {th }}$ century Chinese abalone processing camp at CA-SMI-614H, occupied after the local extinction of sea otters from San Miguel Island. Historically, black abalone (Haliotis cracherodii) were once common in Southern California's intertidal ecosystems and highly susceptible to human predation, while red abalone are largely subtidal and more susceptible to sea otter predation. When sea otters are common, red abalone are largely confined to cracks and fissures, limiting their sizes and densities (Wendell 1994). In the absence of sea otters, abalone populations can become very large and abundant, a phenomenon recorded historically in coastal California (Dayton et al. 1998:317). Using historical shell sizes as a proxy for the structure of a red abalone population released from the effects of otter predation, we compare these measurements to Middle $(-7500-3500$ years ago) and Late Holocene ( -3500 years ago to $\mathrm{AD} 1820)$ red abalone shell measurements from San Miguel Island reported by Erlandson et al. (2008).

Because late $19^{\text {th }}$ century commercial fisheries focused largely on intertidal black abalone, we begin with a discussion of a Chinese-dominated black abalone fishery that began in the mid1800 s, after the local extirpation of sea otters. This early historical fishery provides a baseline for our analysis of prehistoric red abalone exploitation by the Chumash and their ancestors.

\section{Nineteenth Century Sea Otter Hunting and Abalone Predation}

Beginning in the early 1800s, commercial hunting organised by Russian and Euro-American merchants resulted in the local extirpation of sea otters from Southern California waters (Ogden 1941). After the decimation of coastal Native American populations by Old World diseases and the relocation of the Island Chumash to Spanish towns and missions on the mainland by about $\mathrm{AD}$ 1822, abalone populations flourished in the absence of human and sea otter predation. Chinese immigrants were among the first to commercially exploit the rich abalone stocks along the California Coast on a large scale. In the mid-1850s and 1860s, numerous abalone fishing camps were established in the San Francisco, Monterey, Channel Island, San Diego, and Baja California areas (Berryman 1995; Braje and Erlandson 2007; Braje et al. 2007). While subtidal abalone species were also released from predation and their numbers and sizes likely exploded, Chinese fishermen on the Channel Islands largely focused their collecting efforts on easy-toaccess intertidal black abalone along rocky shores, processing and drying the meat on the islands, then shipping their product to overseas markets in China and Japan.

Historic abalone camps have been documented on San Clemente (Axford 1984, 1987; Berryman 1995; McKusick and Warren 1959), San Nicolas (Berryman 1995), Santa Rosa (Bentz 1996; Morris 1994), and San Miguel (Braje et al. 2007) islands. Most of these sites are dominated by large black abalone shells, with some containing hearth features, wood planks, Asian pottery, opium paraphernalia, bullet cartridge casings, and/or metal and glass fragments. Since the commercial sale of abalone shell for ornamental and construction (lime) uses began in the mid1860s (Berryman 1995), most historic abalone middens probably represent the remains of early sites. After the mid-1860s, sites are probably under-represented as fishermen shipped both the 
processed meat and the shell to overseas markets. This is further supported by the lack of red, pink (H. corrugata), green $(H$. fulgens), and white abalone (H. sorenseni) in historic sites, species that were not systematically harvested until the late $18^{\text {th }}$ century when Japanese and Euro-American hardhat divers expanded the industry to include subtidal taxa.

Historic black abalone middens offer an important dataset against which to test prehistoric impacts on sea otter populations and anthropogenic alteration of nearshore ecosystems. These historical sites shed light on an anthropogenic intertidal ecosystem free of sea otters, which were locally extirpated by the 1850s (Scammon 1968:169). As part of a San Miguel Island-wide study of shellfish size changes through the Holocene, Erlandson et al. (2008) compared mean black abalone sizes from six historic sites (using a total of 416 individual shell measurements) to numerous Native American sites spanning the Holocene. They found little evidence for a decline in the size of black abalone shells across the Holocene, but several Middle Holocene assemblages dating between about 6000 and 4000 years ago produced relatively large mean sizes of black abalone shells only slightly smaller than the $19^{\text {th }}$ century sample (Erlandson et al. 2008:Figures 3 and 4 ).

The present study expands this research and focuses on size comparisons between historic period and archaeological red abalone shells. Red abalone shell sizes should be more closely correlated with both human predation pressure and local sea otter populations than were black abalone shell sizes. As a subtidal species, red abalones are a preferred and accessible resource for sea otters. Erlandson et al. (2008:Table 3) demonstrated that red abalone shell samples from the past 9000 years showed a steep and statistically significant decline in the mean size of shells through the Holocene. Although several prehistoric sites between 7500 and 6000 years old yielded mean red abalone shell sizes nearly comparable to those from historic sites, only two historic sites yielded whole red abalone shells, producing just 11 shell measurements and limiting inferences about historic versus prehistoric size changes. Since the discovery of a new historic age site on western San Miguel Island, we have been able to generate a robust sample of post-AD 1850 red abalone shell size measurements and fill an important gap in the dataset.

\section{Site Setting and Results}

In 2005, Dr. Robert DeLong of the National Marine Fisheries Service brought us to a remarkable historic site (CA-SMI-614H) located just behind the beach at Adams Cove near Point Bennett that yielded a large sample of whole, well-preserved red and black abalone shells (Figure 2). According to DeLong, a marine biologist who has worked in the Point Bennett area for over 30 years, Adams Cove is unique on San Miguel Island in having large numbers of red abalone in the intertidal zone. The shoreline adjacent to CA-SMI-614H drops off sharply, is characterised by intensive upwelling of cool waters, and may have been a place where red abalone were available to Chinese fishermen harvesting abalones from the intertidal or shallow subtidal zones. Little archaeological work has been conducted in this area due to its proximity to a large pinniped breeding colony and blowing sands that have reduced visibility and obscured archaeological remains. Due to concerns over disturbing pinnipeds hauled out near the site, we were limited in the amount of time we could spend at CA-SMI-614H. Our investigations, therefore, have been limited to survey, surface collection, site mapping, and small subsurface probes. This work has provided the first sizable assemblage of red abalone shells dating to a $19^{\text {th }}$ century Chinese abalone camp on San Miguel Island.

CA-SMI-614H is a historic site with multiple components scattered across an area of approximately $750 \mathrm{~m}^{2}$. Recent pinniped activity, wave action, and coastal erosion have heavily disturbed the site, mixing modern flotsam with historic debris and older artefacts diagnostic of Early and Late 
Holocene Native American occupations (Braje and Erlandson 2008; Braje et al. 2007). We have conducted several reconnaissance trips to the site to surface collect diagnostic artefacts, record historic features, and map the area. Continued monitoring of the site has been productive as shifting beach and dune sands reveal and obscure cultural materials and features every season. Thus far, we have documented a circular hearth feature, two roughly rectangular rock features, a large assemblage of Asian and Euro-American artefacts including ceramic sherds of Asian origin, sawn Steller sea lion teeth, bullet cartridge casings, and various metal and glass objects.

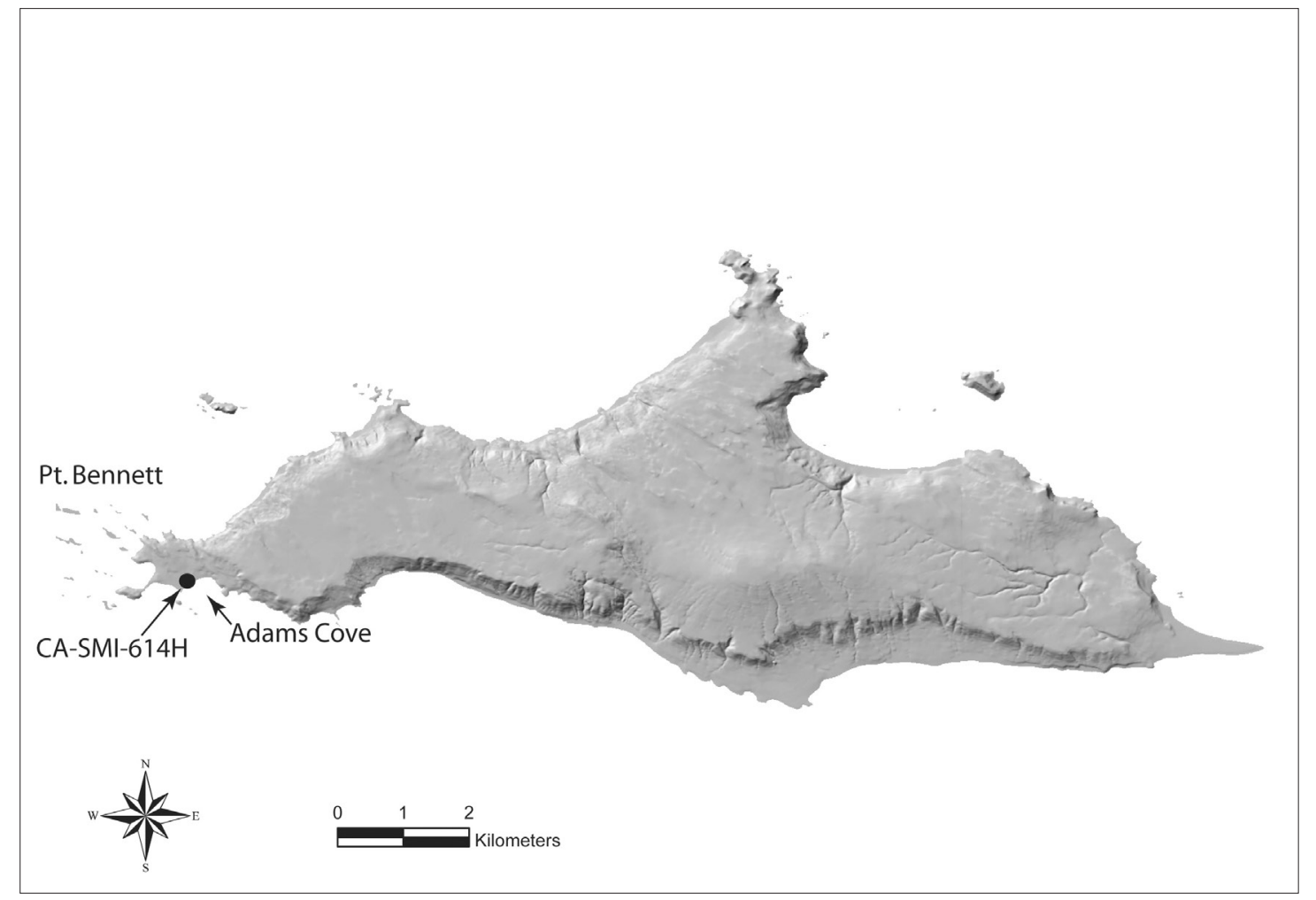

Figure 2. The location of Adams Cove and CA-SMI-614H.

Source: Map by T. Braje.

During a visit in December 2007, shifting sands had exposed a pavement (at least $12 \mathrm{~m}$ eastwest by $9 \mathrm{~m}$ north-south) of whole red and black abalone shells associated with two rectangular rock features (Figure 3). Similar rectangular rock hearths have been recorded elsewhere on San Miguel (Braje et al. 2007) and San Clemente islands (Berryman 2005). Based on the association of the abalone pavement at SMI-614H with these historic hearth features, the presence of historic artefacts embedded within the shells, and the large shell sizes, we are confident that the abalone shells are of 19th century origin. Similar abalone scatters are common at many historic fishing camps on the Channel Islands and probably represent the remnants of shell piles created by some of the first Chinese fishermen to exploit the local intertidal for abalone meat in the mid-1800s.

The CA-SMI- $614 \mathrm{H}$ abalone feature is unique because of the relatively large number of red abalone shells. In a single, randomly selected $1.0 \times 1.0$ m test unit, 9 of 34 (26.5\%) abalone shells were reds. A sample of whole red abalone shells was measured from CA-SMI-614H following methods described by Erlandson et al. (2008). The 65 whole red abalone shells from CA-SMI-614H had an average length of $189.2 \mathrm{~mm}$ (standard deviation $=15.4 \mathrm{~mm}$ ), a maximum length of 214.0 $\mathrm{mm}$, and a minimum of $132.0 \mathrm{~mm}$. In much smaller numbers, red abalone shells have been documented in just two of the other 21 San Miguel Island historic abalone processing sites [CA- 
SMI-553 ( $\mathrm{n}=10)$ and CA-SMI-654H ( $\mathrm{n}=1)]$. To our knowledge, CA-SMI-614H has yielded the largest assemblage of red abalone size measurements from later $19^{\text {th }}$ century Southern California, when abalone populations were largely free of predation by otters and Native American foragers.

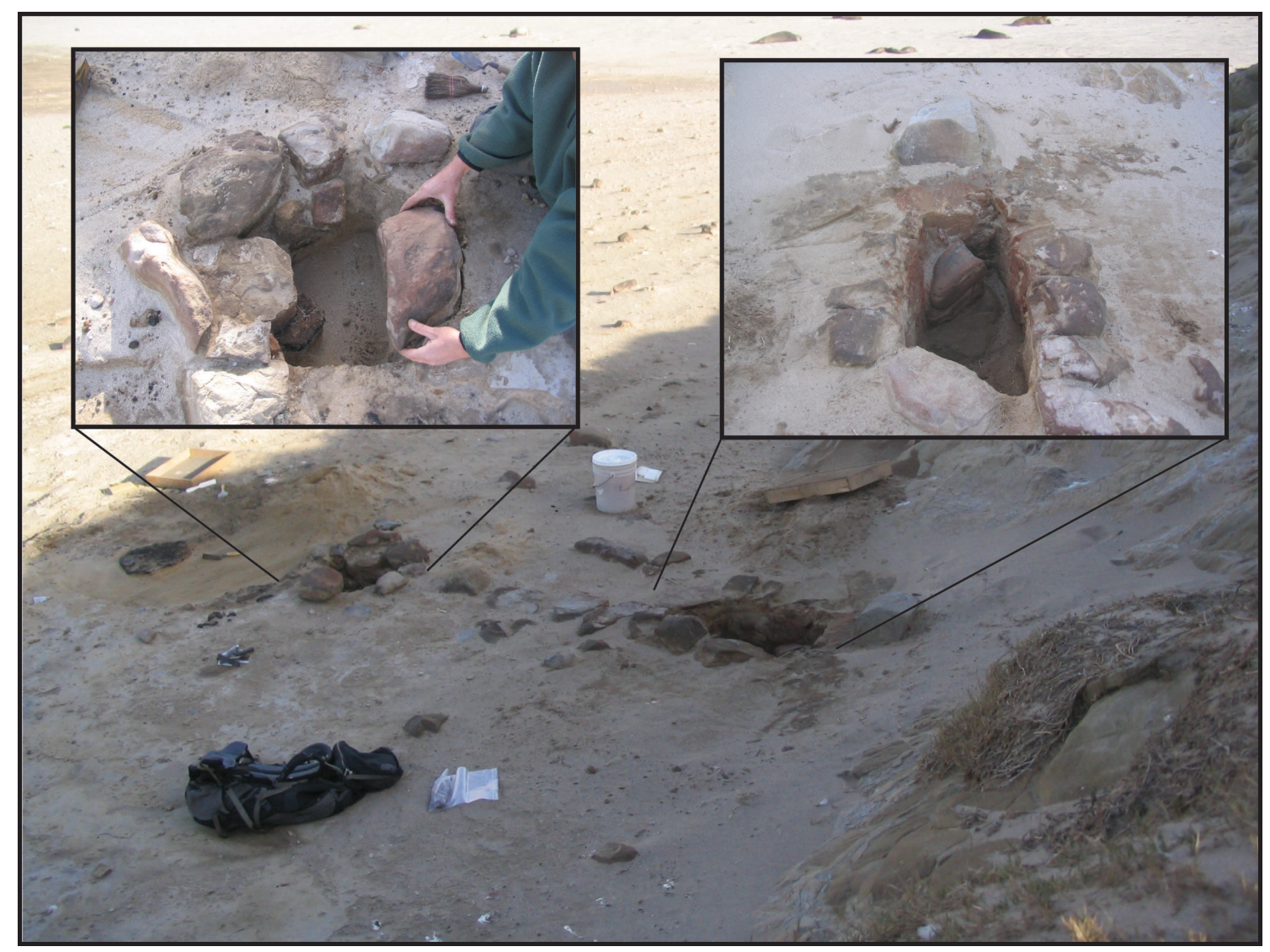

Figure 3. Photograph of one of the two rectangular rock features at CA-SMI-614H.

Source: Photographs and graphic by T. Braje.

Adams Cove may offer a unique set of environmental conditions that allow for abundant red abalone populations in the intertidal, but our data should be comparable to subtidal populations in other locations. Measurements of modern red abalone from marine protected areas without sea otters are nearly equivalent to our Adams Cove sample and environmental reconstructions suggest that marine productivity and sea-surface temperature (SST) were comparable during the Middle Holocene and $19^{\text {th }}$ century (see below).

Red abalone shells are rare in Channel Island sites older than $\sim 8000$ years, but Erlandson et al. (2008:2147) reported a mean shell length of $166.3 \mathrm{~mm}$ ( $\mathrm{n}=548$ shell measurements) from ten Middle Holocene sites on San Miguel Island (Erlandson et al. 2008: Table 1). Average sizes at each site ranged from 188.5 to $124.0 \mathrm{~mm}$. Six sites dated between about 7500 and 4500 years ago produced mean shell sizes approaching the mean for CA-SMI-614H, including CA-SMI-603 at $188.5 \mathrm{~mm}(\mathrm{n}=34)$ and CA-SMI-172 $(\mathrm{n}=131)$ at $186.9 \mathrm{~mm}$. Only three of ten Middle Holocene sites [CA-SMI-161 at $137.8(\mathrm{n}=116)$, CA-SMI-261 at $126.0(\mathrm{n}=4)$, and CA-SMI-628 at 124.0 $(\mathrm{n}=10)$ ] produced means less than $152 \mathrm{~mm}$ (Figure 4). A reduction in average red abalone size occurs from the Middle $(166.3 \mathrm{~mm})$ to Late $(94.4 \mathrm{~mm})$ Holocene, a pattern Erlandson et al. (2008:2147) attributed to human predation and the increased use of large red abalone shells to make dishes, ornaments, beads, and fishhooks after ca. 3500 cal BP (see also Braje et al. 2007; Kennett 2005:193). 


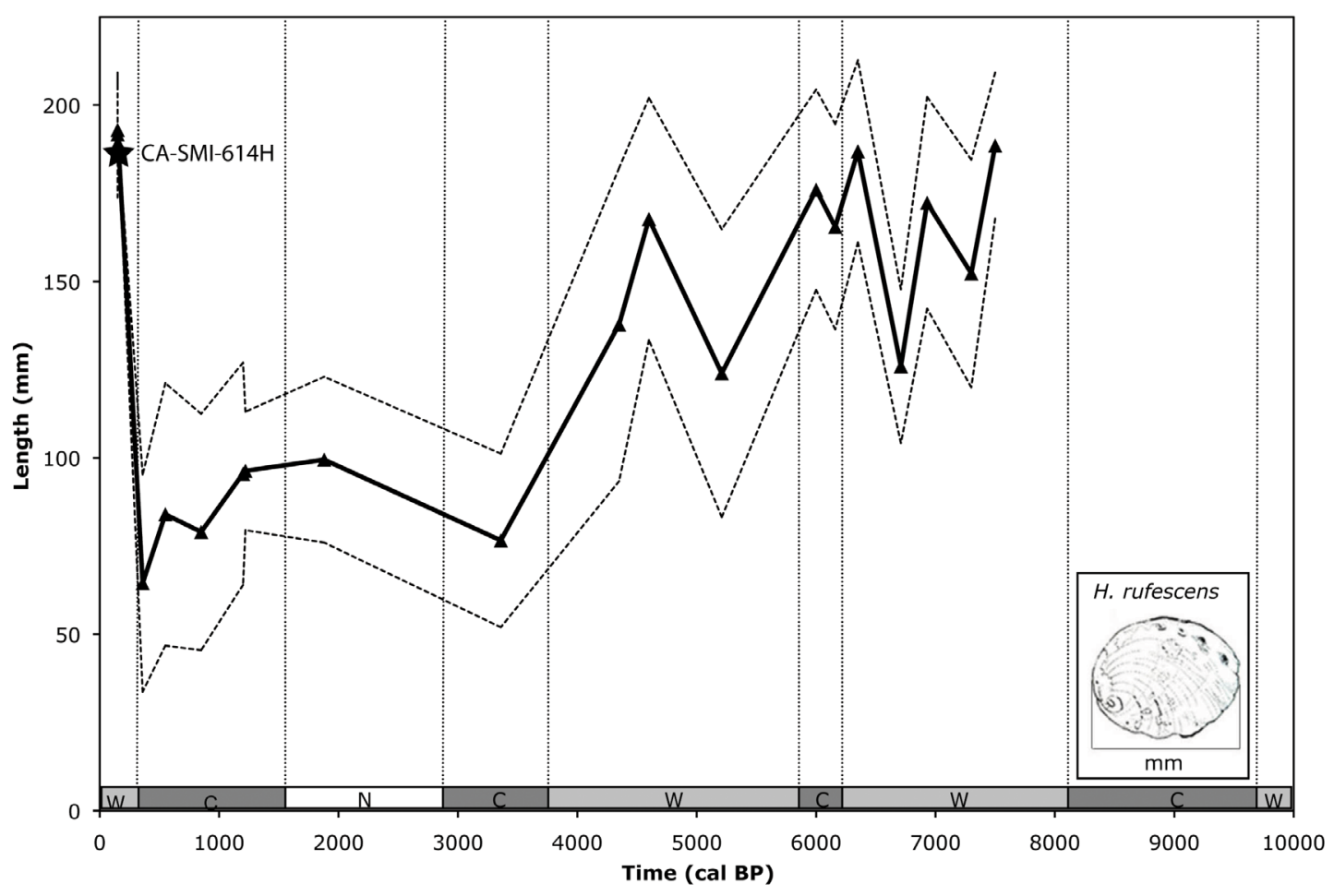

Figure 4. Mean red abalone size changes in San Miguel Island archaeological sites (adapted from Erlandson et al. 2008:2150) and mean red abalone size at CA-SMI-614. Data points are from Table 1 and the dashed lines represent the standard deviation around the mean. The shaded bar along the $x$-axis shows sea-surface temperatures from Kennett (2005): $w=$ warm, $c=$ cold, $n=$ variable.

Source: Figure by T. Braje.

The similarity of the red abalone shell measurements from CA-SMI-614H—occupied $-20-30$ years after sea otters were extirpated from San Miguel Island waters-and the Middle Holocene sites reported by Erlandson et al. (2008) support the notion that Native American hunters suppressed otter populations around the Northern Channel Islands during the Middle Holocene. The maximum size of red abalone shells from several of the Middle Holocene components $(-220$ $230 \mathrm{~mm}$ ) exceeds the largest specimens from our mid $-19^{\text {th }}$ century sites, however, a fact that may be related to the great age $(-20-30$ years $)$ of such individuals and the limited period of growth available between the local extinction of sea otters and the inception of the Chinese abalone fishery.

Palaeoecological reconstructions of SST and marine productivity suggest that marine conditions during the occupation of CA-SMI-614H and the majority of the Middle Holocene were both characterised by periods of predominantly warm SST (Kennett 2005:64-69), so upwelling and marine productivity do not appear to be primarily responsible for larger red abalone size profiles during these times. Even in the Middle Holocene, however, we should not expect mean red abalone sizes to equal historic ones, as otters and humans both appear to have been present as predators in nearshore Channel Island waters. 


\section{Discussion and Conclusions}

Since the collapse of California abalone fisheries in the 1980s and 1990s, marine conservationists and resource managers have worked to develop a sustainable abalone fishery. Except for one highly regulated recreational fishery for red abalone north of San Francisco, there has been a moratorium on all abalone fisheries in California (Jones 2008:66). At best, abalone management and restoration plans have had mixed success and they often put fisheries managers and fishermen at odds with one another. In February 2009, after sixteen years of closure of commercial and recreational harvests, the National Oceanic and Atmospheric Administration (NOAA) granted black abalone endangered species status (Center for Biological Diversity 2006). Today, the commercial abalone market in California is fed exclusively by thirteen abalone farms, where adult abalone (primarily reds ranging in size from $-85-115 \mathrm{~mm}$ ) are grown in tanks (Jones 2008:66). Between 7300 and 4300 years ago, every red abalone shell assemblage measured on San Miguel has mean sizes larger $(>120 \mathrm{~mm})$ than these modern farm-raised red abalone.

Fanshawe et al. (2003) reported demographic data for modern red abalones at nine sites along the California Coast, including six in marine protected areas, four of which had local sea otter populations. They found that sea otter predation restricted abalones to a limited number of microhabitats and to densities and sizes inadequate to sustain a healthy fishery, concluding that "...marine protected areas with sea otters restored as top-level carnivores cannot serve the dual purposes of biodiversity enhancement and abalone fishery conservation off California" (Fanshawe et al. 2003:281). They reported a mean red abalone size of $183 \mathrm{~mm}$ for marine protected areas without sea otters, $142 \mathrm{~mm}$ for unprotected areas without sea otters, and $94 \mathrm{~mm}$ for marine protected areas with sea otters (Fanshawe et al. 2003:Table 3). Mean red abalone sizes from most of the Middle Holocene red abalone middens $(-166 \mathrm{~mm})$ on San Miguel are roughly equivalent to or greater than Fanshawe et al.'s (2003) data from unprotected areas without sea otters and much larger than the marine protected areas with sea otters. All three of the historical assemblages and two of our Middle Holocene assemblages had mean sizes that exceed Fanshawe et al.'s (2003) populations from marine protected areas without sea otters, suggesting that humans harvesting abalones at these sites were collecting "pristine" populations where adult abalones had been largely released from predation pressures.

Archaeological data from CA-SMI-614H provide a rare example of the size of a $19^{\text {th }}$ century red abalone population on San Miguel Island, providing a baseline for a period when sea otters were known to be absent from Channel Island waters. Combined with work by Erlandson et al. (2005) and Braje et al. (2009), these historical data support Fanshawe et al.'s (2003) modern findings, and suggest that a productive red abalone fishery may not have developed on the Channel Islands until -8000 cal BP when Native American hunters began suppressing local sea otter populations. The recent discovery of large red abalone shells in terminal Pleistocene shell middens at CASMI-678 on San Miguel Island - where they are associated with numerous sophisticated projectile points (Erlandson et al. 2011b) — might extend the evidence for localised sea otter depletion back to $\sim 11,600 \mathrm{cal} \mathrm{BP}$, although no sea otter bones have been identified at this or other sites prior to $9000 \mathrm{cal} \mathrm{BP}$. The presence of sea otter bones in San Miguel Island archaeological assemblages for much of the Holocene suggests that a subsistence red abalone fishery persisted and co-existed with sea otters - the latter probably in low densities-on the Northern Channel Islands for at least 8000 years. Average red abalone sizes collected by the Chumash in the Late Holocene were relatively small, but there is no evidence for a wholesale collapse in the fishery until modern, commercial exploitation. 
The precise mechanism behind this balance between productive red abalone fisheries and at least low densities of sea otters remains difficult to establish with existing archaeological data. Comparison of Middle Holocene, $19^{\text {th }}$ century, and modern ecological datasets suggests that the abundance and large sizes of prehistoric red abalones may only have been reached through the human suppression of sea otter populations. As it did historically, substantial reduction in prehistoric sea otter populations would have caused an ecological re-organisation in the nearshore environment where humans replaced otters as the keystone abalone predator. This resulted in a highly productive red abalone fishery on the Channel Islands during the Middle Holocene.

Historical, archaeological, and ecological data suggest that a limited but sustainable red abalone fishery and the recovery of sea otters may be able to co-exist in California. This would require, however, a healthy (fully recovered) red abalone population and a carefully controlled sea otter population. Future debates between ecologists and environmental advocates who call for sea otter recovery in Southern California waters and fisherfolk who yearn to restore economically productive abalone harvests may be mediated by a better understanding of the archaeological and historical relationships between humans, otters, and abalone over the last 8000 years.

Continued archaeological, historical, and ecological research on the Channel Islands may provide historical baselines and ecological linkages to guide effective recovery and management plans and help further investigate the relationships between ancient peoples, sea otters, and kelp forest ecosystems. For now, archaeological data lend some support to the notion that healthy red abalone populations and sustainable human fishing practices can co-exist with sea otter populations, but only where both human harvests and the density of sea otter populations are carefully monitored and controlled. Sustaining such a fishery in modern times may only succeed if various parties compromise by limiting commercial and recreational harvests of red abalones to sustainable levels, as well as limiting the density or distribution of sea otter populations within a broader geographic range. Ultimately, it will be critical to determine how to best mediate the conflicting requirements of restoring and protecting endangered populations of sea otters and abalones, especially when one endangered species feeds on the other.

\section{Acknowledgments}

Our research was supported by the National Science Foundation (BCS-0613982 to Braje and Erlandson), Channel Islands National Park (CINP), the Western National Parks Association, and our home institutions. We are indebted to Bob DeLong (U.S. National Marine Fisheries Service) for facilitating our work at CA-SMI-614H. At CINP, we thank Ann Huston, Kelly Minas, and Ian Williams for their support. We are grateful to David Addison, Rintaro Ono, Ian Smith, and an anonymous reviewer for their constructive comments and assistance in the revision and final production of this paper.

\section{References}

Axford, M. 1984. Four years of archaeological investigations on San Clemente Island, California. Manuscript on file. San Diego: Natural Resource Office, North Island Naval Reservation.

Axford, M. 1987. Late historic Chinese abalone collectors on San Clemente Island. Manuscript on file, San Diego: Natural Resource Office, North Island Naval Reservation.

Bentz, L. 1996. Chinese abalone collectors of Santa Rosa Island. presented for contract fulfillment to National Park Service, Channel Islands National Park. 
Berryman, J.A. 1995. Archival information, abalone shell, broken pots, hearths, and windbreaks: Clues to identifying nineteenth century California abalone collection and processing sites, San Clemente Island: A case study. Unpublished doctoral dissertation, Department of Anthropology, University of California, Riverside.

Braje, T.J. 2010. Modern oceans, ancient sites: Archaeology and marine conservation on San Miguel Island, California. Salt Lake City: University of Utah Press.

Braje, T.J. and J.M. Erlandson. 2007. Measuring subsistence specialization: Comparing historic and prehistoric abalone middens on San Miguel Island, California. Journal of Anthropological Archaeology 26:474-485.

Braje, T.J. and J.M. Erlandson. 2008. Early maritime technology from western San Miguel Island, California. Current Research in the Pleistocene 25:31-32.

Braje, T.J., J.M. Erlandson, and T.C. Rick. 2007. A historic abalone fishery on California's Northern Channel Islands. Historical Archaeology 41(4):117-128.

Braje, T.J., J.M. Erlandson, T.C. Rick, P.K. Dayton, and M.B.A. Hatch. 2009. Fishing from past to present: Long-term continuity and resilience of red abalone fisheries on California's Northern Channel Islands. Ecological Applications 19(4):906-919.

Center for Biological Diversity. 2006. Petition to list the black abalone (Haliotis cracherodii) as threatened or endangered under the endangered species act. Submitted to the United States Secretary of Commerce, 21 December 2006.

Dayton, P. 1985. Ecology of kelp communities. Annual Review of Ecology and Systematics 16:215-245.

Dayton, P.K., and M.J. Tegner. 1984. The importance of scale in community ecology: A kelp forest example with terrestrial analogs. In P.W. Price, C.N. Slobodchikoff, and W.S. Gaud (eds), A New Ecology: Novel Approaches to Interactive Systems, pp. 457-481. New York: John Wiley and Sons.

Dayton, P.K., M.J. Tegner, P.B. Edwards, and K.L. Riser. 1998. Sliding baselines, ghosts, and reduced expectations in kelp forest communities. Ecological Applications 8:309-322.

Erlandson, J.M. and T.J. Braje. 2008. Five crescents from Cardwell: The context of eccentric crescents from CA-SMII-679, San Miguel Island, California. Pacific Coast Archaeological Society Quarterly 40(1):35-45.

Erlandson, J.M., T.C. Rick, and T.J. Braje. 2009. Fishing up the food web?: 12,000 years of maritime subsistence and adaptive adjustments on California's Channel Islands. Pacific Science 63(4):711-724.

Erlandson, J.M., T.J. Braje, T.C. Rick, N.P. Jew, D.J. Kennett, N. Dwyer, A.F. Ainis, R.L. Vellanoweth, and J. Watts. 2011a. 10,000 years of human predation and size changes in the owl limpet (Lottia gigantea) on San Miguel Island, California. Journal of Archaeological Science 38:1127-1134.

Erlandson, J.M., T.C. Rick, T.J. Braje, M. Casperson, B. Culleton, B. Fulfrost, T. Garcia, D.A. Guthrie, N. Jew, D.J. Kennett, M.L. Moss, L. Reeder, C. Skinner, J. Watts, and L. Willis. 2011 b. Paleoindian seafaring, maritime technologies, and coastal foraging on California's Channel Islands. Science 331:1181-1185.

Erlandson, J.M., T.C. Rick, T.J. Braje, A. Steinberg, and R.L. Vellanoweth. 2008. Human impacts on ancient shellfish: A 10,000 year record from San Miguel Island, California. Journal of Archaeological Science 35:2144-2152.

Erlandson, J.M., T.C. Rick, J.A. Estes, M.H. Graham, T.J. Braje, and R.L. Vellanoweth. 2005. Sea otters, shellfish, and humans: A 10,000 year record from San Miguel Island, California. In D. Garcelon and C.A. Schwemm (eds), Proceedings of the Sixth California Islands Conference, pp. 9-21. Arcata: Institute for Wildlife Studies. 
Estes, J.A. and D.O. Duggins. 1995. Sea otters and kelp forests in Alaska: Generality and variation in a community ecological paradigm. Ecological Monographs 65:75-100.

Estes, J.A., R.J. Jameson, and A.M. Johnson. 1981. Food selection and some foraging tactics of sea otters. In J.A. Chapman and D. Pursley (eds), Worldwide Furbearer Conference Proceedings, pp. 606641. Frostburg: Worldwide Furbearer Conference, Inc.

Fanshawe, S., G.R. VanBlaricom, and A.A. Shelly. 2003. Restored top carnivores as detriments to the performance of marine protected areas intended for fishery sustainability: A case study with red abalones and sea otters. Conservation Biology 17:273-283.

Glassow, M.A., P. Paige, and J. Perry. 2008. The Punta Arena site: Early and Middle Holocene cultural development on Santa Cruz Island, California. Santa Barbara: Santa Barbara Museum of Natural History. Santa Barbara Museum of Natural History Contributions in Anthropology No. 3.

Graham. M. H., B. Halpern, and M. Carr. 2008. Diversity and dynamics of Californian subtidal kelp forests. In T.R. McClanahan and G.M. Branch (eds), Food webs and the dynamics of marine reefs, pp. 103-134. New York: Oxford University Press.

Jackson, J.B.C., M.X. Kirby, W.H. Berger, K.A. Bjorndal, L.W. Botsford, B.J. Bourque, R.H. Bradbury, R. Cooke, J. Erlandson, J.A. Estes, T.P. Hughes, S. Kidwell, C.B. Lange, H.S. Lenihan, J.M. Pandolfi, C.H. Peterson, R.S. Steneck, M.J. Tegner, and R.R. Warner. 2001. Historical overfishing and the recent collapse of coastal ecosystems. Science 293:629-637.

Jones, G.A. 2008. 'Quite the choicest protein dish': The costs of consuming seafood in American restaurants, 1850-2006. In D.J. Starkey, P. Holm, and M. Barnard (eds), Ocean's past: Management insights from the history of marine animal populations, pp. 47-76, 606-641. London: Earthscan.

Kennett, D.J. 2005. The Island Chumash: Behavioral ecology of a maritime society. Berkeley: University of California Press.

Lotze, H.K., H.S. Lenihan, B.J. Bourque, R.H. Bradbury, R.G. Cooke, M.C. Kay, S.M. Kidwell, M.X. Kirby, C.H. Peterson, and J.B.C. Jackson. 2006. Depletion, degradation, and recovery potential of estuaries and coastal seas. Science 312:1806-1809.

McKusick, M.B. and C.N. Warren. 1959. Introduction to San Clemente Island archaeology. Los Angeles: University of California. University of California Los Angeles Archaeological Survey Annual Report 1:106-183.

Morris, D.P. 1994. Santa Rosa Island survey. Paper presented at the Fourth California Islands Symposium. Santa Barbara: Santa Barbara Museum of Natural History.

Ogden, A. 1941. The California sea otter trade 1784-1848. Berkeley: University of California Press.

Pauly, D., V. Christensen, J. Dalsgaard, R. Froese, and F. Torres Jr. 1998. Fishing down marine food webs. Science 279:860-863.

Rick, T.C. and J.M. Erlandson (eds). 2008. Human impacts on ancient marine ecosystems: A global perspective. Berkeley: University of California Press.

Rick, T.C., J.M. Erlandson, T.J. Braje, J.E. Estes, M.H. Graham, and R.L. Vellanoweth. 2008. Historical ecology and human impacts on coastal ecosystems of the Santa Barbara Channel region, California. In T.C. Rick and J.M. Erlandson (eds), Human impacts on ancient marine ecosystems: A global perspective, pp. 77-101. Berkeley: University of California Press.

Scammon, C.M. 1968. The marine mammals of the northwestern coast of North America. New York: Dover. 
Sharp, J.T. 2000. Shellfish analysis from the Punta Arena site, a Middle Holocene red abalone midden on Santa Cruz Island, California. Unpublished master's thesis, Department of Anthropology, Sonoma State University.

Simenstad, C.A., J.A. Estes, and K.W. Kenyon. 1978. Aleuts, sea otters, and alternate stable-state communities. Science 200:403-411.

Steneck, R.S., M.H. Graham, B.J. Bourque, D. Corbett, J.M. Erlandson, J.A. Estes, and M.J. Tegner. 2002. Kelp forest ecosystems: Biodiversity, stability, resilience, and future. Environmental Conservation 29(4):436-459.

Wendell, F. 1994. Relationship between sea otter range expansion and red abalone abundance and size distribution in central California. California Fish and Game 80:45-56.

Worm, B., E.B. Barbier, N. Beaumont, J.E. Duffy, C. Folke, B.S. Halpern, J.B.C. Jackson, H.K. Lotze, F. Micheli, S.R. Palumbi, E. Sala, K.A. Selkoe, J.J. Stachowicz, and R. Watson. 2006. Impacts of biodiversity loss on ocean ecosystem services. Science 314:787-790. 